\title{
Editorial
}

Allergy
Immunomational archive of
Immulogy

Published online: March 1, 2012

DOI: $10.1159 / 000333096$

\section{Aspirin-Exacerbated Asthma: Avoiding Challenge Is Still Challenging}

\author{
Giovanni Rolla Enrico Heffler \\ Allergy and Clinical Immunology, Department of Biomedical Sciences and Human Oncology, AO Mauriziano \\ 'Umberto I', University of Turin, Turin, Italy
}

The term 'aspirin-exacerbated respiratory disease' (AERD), instead of the formerly used 'aspirin-induced asthma', highlights that the core issue for these patients is not drug hypersensitivity, but the underlying chronic inflammatory respiratory disease, occasionally exacerbated by aspirin or other nonsteroidal anti-inflammatory drugs (NSAIDs) [1].

The gold standard for diagnosing AERD is aspirin challenge, which may be performed through three different routes of provocation challenges: oral, bronchial and nasal inhalation, the oral challenge being considered the test with the best sensitivity and specificity [2].

As well as being time-consuming, aspirin challenges are not without risk, and more than a third of patients have been reported to experience late reactions following bronchial aspirin challenge [3]. For these reasons, in vitro tests would be welcome, but unfortunately, till now, none could be recommended for routine diagnosis [4]. More recently, three in vitro tests measuring aspirin/NSAIDsspecific peripheral blood leukocyte activation have been proposed: measurement of sulfidoleukotriene release with inconsistent results $[5,6]$, measurement of cell surface molecule CD63 expression upon in vitro challenge [7] with quite variable specificity and sensitivity and measurement of aspirin-triggered 15-HETE generation, which appears to be promising [8]. Its clinical usefulness has, however, not yet been confirmed by larger studies.
AERD is an organ-specific disease, characterized by abnormalities in the biosynthesis of eicosanoid mediators and eicosanoid receptor expression. The biochemical hallmark of AERD is enhanced cysteinyl leukotriene (CysLT) production both at baseline $[9,10]$ and following aspirin challenge $[11,12]$.

As AERD is not a systemic disease, it is not surprising that studies of different inflammatory cells in the blood have so far failed to produce consistent support for specific NSAID-induced ex vivo activation of cells from subjects with AERD. Higashi et al. [13], in this issue, reason that acetylsalicylic acid intolerance might be maintained in sputum cells when they are recovered from the lower airways of patients with asthma, if these cells were challenged by aspirin ex vivo. They found that release of CysLTs by sputum cells from patients with AERD was neither induced by aspirin ex vivo when cells were collected at baseline nor in sputum cells recovered after lysine-aspirin-induced bronchoconstriction. On the other hand, they found that the release of CysLTs from sputum cells triggered by ionophores in both instances was higher in the AERD group, both at baseline and after the lysine-aspirin bronchoprovocation. Their results confirm that AERD is characterized by enhanced CysLTs production both at baseline and following aspirin challenge. The difference in the amounts of CysLT release between aspirin-sensitive and aspirin-tolerant asthmatic patients ap-

\section{KARGER}

Fax +4161306 1234

E-Mail karger@karger.ch

www.karger.com (c) 2012 S. Karger AG, Basel

$1018-2438 / 12 / 1583-0213 \$ 38.00 / 0$

Accessible online at:

www.karger.com/iaa
Correspondence to: Prof. Giovanni Rolla

Allergologia ed Immunologia Clinica, AO Mauriziano 'Umberto I'

Largo Turati 62

IT-10128 Torino (Italy)

Tel. +39011508 2083, E-Mail grolla@mauriziano.it 
peared related to the number of eosinophils. AERD is actually an eosinophilic phenotype of asthma and chronic rhinosinusitis.

The inability to demonstrate intolerance to NSAIDs in blood cells as well as in sputum cells strongly points to the role of airway resident cells in the adverse reaction.

Two cells appear to be the best candidates to explain acute asthma exacerbation following aspirin challenge: airway epithelial cells and bronchial mast cells, neither of which is represented in peripheral blood or in sputum cells.

Downregulation of COX-1 has been shown in the airway epithelial cells of patients with AERD; this may result in a further decrease of prostaglandin $\mathrm{E}_{2}\left(\mathrm{PGE}_{2}\right)$ production upon NSAIDs administration [14]. There is evidence that $\mathrm{PGE}_{2}$ ameliorates aspirin-induced disease, at least partly, by inhibiting excessive CysLTs synthesis $[5,15]$. Mast cells are a major source of the release of the autacoid mediators histamine, prostaglandin $\mathrm{D}_{2}\left(\mathrm{PGD}_{2}\right)$ and leukotriene $\mathrm{C}_{4}\left(\mathrm{LTC}_{4}\right)$ [16], all of which are potent contractile agonists of airway smooth muscle. In vivo studies suggest that mast cells are directly activated by aspirin in AERD. Aspirin-sensitive patients have raised levels of the PGD2 metabolite $(9 \alpha, 11 \beta$-PGF2) and tryptase in their blood prior to exposure to aspirin. In most patients, following challenge, these levels rise still further [17]. After segmental lysine aspirin challenge a trend in patients towards an increased histamine release with no inhibition of PGD2 production has been shown [11]. Conversely, in mast cells cultured from peripheral blood progenitors in aspirinsensitive patients, neither baseline nor IgE-induced release of histamine or CysLTs was upregulated when the cells were incubated with aspirin [18]. Overall, these findings suggest that chronic ongoing mast cell activation is a feature of AERD at baseline, and this may be aggravated further as a result of aspirin provocation. However, a mechanism for direct mast cell activation by aspirin is unclear. A possible explanation may reside in the cross talk between airway epithelial cells and bronchial mast cells. At baseline, as a result of an unknown injury (bacterial?), airway epithelial cells produce tissue cytokines (i.e. thymic stromal lymphopoietin) [19] which drive Th2 inflammation, characterized by heavy eosinophil and mast cell infiltration of bronchial mucosa [20]. These cells may be the source of leukotrienes and PGD2, which have been reported to increase at baseline and after aspirin challenge in a wide variety of biological samples of patients with AERD. Moreover, mast cells secrete the proinflammatory cytokines interleukin IL-4, which upregulates both the pathway responsible for CysLTs synthesis and the expression of CysLT receptors [21, 22], IL-13, which selectively downregulates PGE2 biosynthesis while upregulating the PGE2-metabolizing enzyme 15-prostaglandin dehydrogenase in human airway epithelial cells [23] and IL-5, which plays a major role in recruitment and survival of eosinophils. Eosinophils, in turn, are a major source of the same cytokines, so that they may contribute to amplify and maintain airway inflammation.

As not all patients with Th2-driven asthma develop AERD, inherited susceptibility may probably play a role [24].

In conclusion, although AERD is a relatively common phenotype of asthma, affecting primarily adults but also children with physician-diagnosed asthma, it is often unrecognized and underdiagnosed. Unfortunately, there is no simple in vitro test to diagnose AERD and in vivo aspirin challenge still remains the gold standard. Ex vivo stimulation of sputum cells nevertheless appears a promising method to assess capacity for CysLT production in the airways of subjects with asthma. It would be useful to evaluate novel therapeutic approaches targeting aspirinsensitive patients.

\section{References}

1 Berges-Gimeno MP, Simon RA, Stevenson DD: The natural history and clinical characteristics of aspirin-exacerbated respiratory disease. Ann Allergy Asthma Immunol 2002;89:474-478.

2 Nizankowska-Mogilnicka E, Bochenek G, Mastalerz L, Swierczyńska M, Picado C, Scadding G, Kowalski ML, Setkowicz M, Ring J, Brockow K, Bachert C, Wöhrl S, Dahlén B, Szczeklik A: EAACI/GA2LEN guideline: aspirin provocation tests for diagnosis of aspirin hypersensitivity. Allergy 2007;10:1111-1118.
-3 Makowska JS, Grzegorczyk J, Bienkiewicz B, Wozniak M, Kowalski ML: Systemic responses after bronchial aspirin challenge in sensitive patients with asthma. J Allergy Clin Immunol 2008;121:348-354.

4 Kowalski ML: Diagnosis of aspirin sensitivity in aspirin exacerbated respiratory disease; in Pawankar R, Holgate ST, Rosenwasser LJ (eds): Allergy Frontiers: Diagnosis and Health Economics. Tokyo, Springer, 2009, pp 349-372.
5 Celik G, Bavbek S, Misirligil Z, Melli M: Release of cysteinyl leukotrienes with aspirin stimulation and the effect of prostaglandin $E(2)$ in this release from peripheral blood leucocytes in aspirin-induced asthmatic patients. Clin Exp Allergy 2001;31:1615-1622.

6 Pierzchalska M, Mastalerz L, Sanak M, Zazula M, Szczeklik A: A moderate and unspecific release of cysteinyl leukotrienes by aspirin from peripheral blood leucocytes precludes its value for aspirin sensitivity testing in asthma. Clin Exp Allergy 2000;30:17851791. 
7 Gamboa P, Sanz ML, Caballero MR, Urrutia I, Antepara I, Esparza R, de Weck AL: The flow-cytometric determination of basophil activation induced by aspirin and other nonsteroidalanti-inflammatory drugs(NSAIDs) is useful for in vitro diagnosis of the NSAID hypersensitivity syndrome. Clin Exp Allergy 2004;34:1448-1457.

$>8$ Kowalski ML, Ptasinska A, Jedrzejczak M, Bienkiewicz B, Cieslak M, Grzegorczyk J, Pawliczak R, Dubuske L: Aspirin-triggered 15-HETE generation in peripheral blood leukocytes is a specific and sensitive aspirinsensitive patients identification test (ASPITest). Allergy 2005;60:1139-1145.

$>9$ Higashi N, Taniguchi M, Mita H, Kawagishi Y, Ishii T, Higashi A, Osame M, Akiyama K: Clinical features of asthmatic patients with increased urinary leukotriene E4 excretion (hyperleukotrienuria): involvement of chronic hyperplastic rhinosinusitis with nasal polyposis. J Allergy Clin Immunol 2004; 113:277-283.

10 Antczak A, Montuschi P, Kharitonov S, Gorski P, Barnes PJ: Increased exhaled cysteinyl leukotrienes and 8-isoprostane in aspirininduced asthma. Am J Respir Crit Care Med 2002;166:301-306.

-11 Szczeklik A, Sladek K, Dworski R, Nizankowska E, Soja J, Sheller J, Oates J: Bronchial aspirin challenge causes specific eicosanoid response in aspirin-sensitive asthmatics. Am J Respir Crit Care Med 1996;154: 1608-1614.

12 Fischer AR, Rosenberg MA, Lilly CM, Callery JC, Rubin P, Cohn J, White MV, Igarashi Y, Kaliner MA, Drazen JM, et al: Direct evidence for a role of the mast cell in the nasal response to aspirin in aspirin-sensitive asthma. J Allergy Clin Immunol 1994;94:10461056.
13 Higashi A, Kumlin M, Higashi N, Daham K, Gaber F, Lindeberg A, James A, Skedinger M, Delin I, Gyllfors P, Dahlen SE, Dahlen B: Challenge of isolated sputum cells supports in vivo origin of aspirin/NSAID intolerance reaction in asthma. Int Arch Allergy Immunol 2012;158:299-306.

14 Pierzchalska M, Soja J, Woś M, Szabó Z, Nizankowska-Mogielnicka E, Sanak M, Szczeklik A: Deficiency of cyclooxygenases transcripts in cultured primary bronchial epithelial cells of aspirin-sensitive asthmatics. J Physiol Pharmacol 2007;58:207-218.

15 Sestini P, Armetti L, Gambaro G, Pieroni MG, Refini RM, Sala A, Vaghi A, Folco GC, Bianco S, Robuschi M: Inhaled PGE2 prevents aspirin-induced bronchoconstriction and urinary LTE4 excretion in aspirin-sensitive asthma. Am J Respir Crit Care Med 1996;153:572-575.

16 Bradding P, Walls AF, Holgate ST: The role of the mast cell in the pathophysiology of asthma. J Allergy Clin Immunol 2006;117: 1277-1284.

17 Bochenek G, Nagraba K, Nizankowska E, Szczeklik A: A controlled study of 9alpha,11beta-PGF2 (a prostaglandin D2 metabolite) in plasma and urine of patients with bronchial asthma and healthy controls after aspirin challenge. J Allergy Clin Immunol 2003; 111:743-749.

18 Wang XS, Wu AY, Leung PS, Lau HY: PGE suppresses excessive anti-IgE induced cysteinyl leucotriene production in mast cells of patients with aspirin exacerbated respiratory disease. Allergy 2007;62:620-627.
9 Ozawa T, Koyama K, Ando T, Ohnuma Y, Hatsushika K, Ohba T, Sugiyama H, Hamada Y, Ogawa H, Okumura K, Nakao A: Thymic stromal lymphopoietin secretion of synovial fibroblasts is positively and negatively regulated by Toll-like receptors/nuclear factorkappaB pathway and interferon-gamma/ dexamethasone. Mod Rheumatol 2007;17: 459-463.

20 Varga EM, Jacobson MR, Masuyama K, Rak S, Till SJ, Darby Y, Hamid Q, Lund V, Scadding GK, Durham SR: Inflammatory cell populations and cytokine mRNA expression in the nasal mucosa in aspirin-sensitive rhinitis. Eur Respir J 1999;14:610-615.

21 Hsieh FH, Lam BK, Penrose JF, Austen KF, Boyce JA: T helper cell type 2 cytokines coordinately regulate immunoglobulin E-dependent cysteinyl leukotriene production by human cord blood-derived mast cells: profound induction of leukotriene C(4) synthase expression by interleukin 4. J Exp Med 2001; 193:123-133.

-22 Thivierge M, Stanková J, Rola-Pleszczynski M: IL-13 and IL-4 up-regulate cysteinyl leukotriene 1 receptor expression in human monocytes and macrophages. J Immunol 2001;167:2855-2860

23 Trudeau J, Hu H, Chibana K, Chu HW, Westcott JY, Wenzel SE: Selective downregulation of prostaglandin E2-related pathways by the Th2 cytokine IL-13. J Allergy Clin Immunol 2006;117:1446-1454.

24 Kim SH, Hur GY, Choi JH, Park HS: Pharmacogenetics of aspirin-intolerant asthma. Pharmacogenomics 2008;9:85-91. 